\title{
A comprehensive review of therapeutic agents used in the treatment of recurrent aphthous ulcer and oral ulcers in Bechet's syndrome
}

\author{
Sheshaprasad R.,"*, Anuradha Pai ${ }^{2}$ \\ ${ }^{1}$ Senior Lecturer, ${ }^{2}$ Professor \& HOD, Dept. of Oral Medicine and Radiology, The Oxford Dental College an Hospital, Bengaluru, \\ Karnataka, India
}

*Corresponding Author:

Email: drsheshaprasad@gmail.com

\begin{abstract}
Introduction: Recurrent aphthous ulcer (RAU) is a common oral disease characterized by ulcers with an erythematous halo, affecting 5-25\% of the general population. The underlying etiology is not clear, but several factors are believed to be responsible for the pathogenesis of the disease including stress, hormones, genetic factors etc. Behcet'ssyndrome is a multisystem disorder involving vasculitis of small and medium-sized vessels and inflammation of the epithelium, characterized by recurring oral and genital ulcers with eye lesions.

Aim: The objectives of this paper were to compare different treatment options available for the patients suffering from RAU and major refractory oral aphthae without any systemic disease or any syndromes except Bechet's, associated with RAU published in the review of RAU, point out drugs and therapies along with their dosages that may be used in the first line of treatment (topical) and second line of treatment (systemic).

Materials and Methods: Pub Med search (full text and abstracts) with drugs belonging to several categories like anesthetics; antibiotics and antiseptics, corticosteroids, anti-inflammatory and antiallergic drugs hemorrheologic agents, zinc substitutes, immunomodulatory agents and chemical cauterizing agents was done. Pub Med search term "Behcet's trial oral" was used and only those publications that described clinical trial with drugs on patients with Behcet's disease involving oral lesions were selected.

Result: Total 62 articles were analyzed to extract the data regarding different therapeutic agents used in the treatment of Recurrent aphthous ulcer and oral ulcers in Bechet's syndrome. The drugs most commonly used were lidocaine, benzocaine, tetracycline, chlorehexidine amlexenox and dexamethasone topically and prednisolone, levamisole and thalidomide systemically as a single therapy or in combination. The impact of immunomodulators and LASER in comparison with topical drugs also was assessed.

Conclusion: Novel research strategies should be designed to clinically test combination therapies in the treatment of aphthous ulcers.
\end{abstract}

Keywords: RAU, aphthous ulcers, Bechet's syndrome.

\section{Introduction}

Recurrent aphthous ulcer (RAU) is a common oral disease characterized by ulcers with an erythematous halo, affecting $5-25 \%$ of the general population. ${ }^{1-4}$ The underlying etiology is not clear, but several factors are believed to be responsible for the pathogenesis of the disease, which include genetic factors, food allergens, local trauma, hormonal changes (menstrual cycle), stress, anxiety, smoking cessation, chemical products, and microorganism such as $\mathrm{H}$. pylori. ${ }^{1-3,5,6}$ Tumor necrosis factor (TNF) is also believed to play an important role in the formation of RAU lesions. ${ }^{2}$ An increase in the expression of vascular and keratinocyte adhesion molecules is observed in the lesion. Accumulation of lymphocytes and lymphocyte infiltration of the epithelium is a common occurrence, which results in ulcer formation. ${ }^{1,2,7}$

Based on size, RAU is classified into three types: small ulcers or Mikulicz aphthous ulcers, large ulcers or Suttons disease, and herpetiform ulcers. Small ulcers of the minor type (Mikulicz) are less than $1 \mathrm{~cm}$ in diameter and represent $80-90 \%$ of all recurrent oral aphthous ulcers. ${ }^{8,9}$ Large ulcers of the major type (Suttons disease) are usually $1-3 \mathrm{~cm}$ in diameter and account for approximately $10 \%$ of recurrent benign oral ulcers. ${ }^{8} 10$ Herpetiform aphthous ulcers are very small (1-2 mm), which account for 5\% of RAU and are very painful. 8,11

RAU is also one of the most common diseases associated with Behcet's syndrome, characterized by recurring oral and genital ulcers with eye lesions. ${ }^{12}$ Behcet'ssyndrome is a multisystem disorder involving vasculitis of small and medium-sized vessels and inflammation of the epithelium. The abnormal inflammatory response in Behcet's syndrome is caused by the T-lymphocytes and plasma cells. Although Behcet's syndrome generally affects adults, it is not uncommon in children. ${ }^{13-15}$ Distinguishing RAU and Behcet's disease clinically is challenging. However, an effective test is developed in which a high titer of antiSaccharomyces cerevisiae antibodies (ASCA) has been detected in patients with Behcet's syndrome compared with that of RAS and healthy individuals. ${ }^{16}$ Although ASCA test can be used to distinguishing between patients with RAU and Behcet's; however, it may not be accurate, as $70 \%$ of patients with Crohn's disease and $15 \%$ of patients with ulcerative colitis are ASCA 
positive and both of the diseases are associated with recurring oral ulcers.

Apart from Behcet's syndrome, many other ulcerative conditions may be confused with RAU, including primary herpetic gingivostomatitis, cyclic neutropenia, pemphigus vulgaris, benign mucous membrane pemphigoid, herpangina, mouth and genital ulcers with inflamed cartilage (MAGIC syndrome), periodic fever, aphthous stomatitis, pharyngitis, and cervical adenitis (PFAPA). These conditions should be considered before starting the treatment of RAU. Oral ulceration may also indicate underlying or developing systemic disease; the definitive diagnosis of which may not be possible until later in the disease process. Therefore a dental surgeon should continually monitor the patient and collaborate with the medical colleagues to distinguish between RAU, ulcerative colitis, and Crohn's disease. Treatment of RAU involves a list of drugs and combined use of therapies. Several drugs such as antiseptics, anesthetics, anti-inflammatory, corticosteroids, and laser therapies are common recommendations. Both topical and systemic therapies are employed to treat the disease. There are the drugs, which are used to treat RAU without any systemic abnormalities and RAU in Behcet's syndrome. In this article, we performed a systematic review of clinical trials involving several therapeutic approaches to treat RAU without any other systemic abnormalities and oral aphthous ulcers in Behcet's syndrome. Similar analysis was performed and reported by a study done by Andreas et al. ${ }^{17}$ using Pub Med and Cochrane Central Register of Controlled Trials database. A literature review was also performed by Irene et al. ${ }^{18}$ who searched Pub Med, Cochrane, and Scopus databases by using the keywords such as recurrent aphthous stomatitis, treatment and clinical management, combined and related by means of the Boolean operator-AND. In our systematic review, we used search terms in an effective manner and performed several analysis strategies to present comprehensive information on RAU.

The objectives of this paper were to compare different treatment options available for the patients suffering from RAU and major refractory oral aphthae without any systemic disease or syndrome other than Behcet's syndrome, enlist the suggestions published in the review of RAU, point out drugs and therapies along with their dosages that may be used in the first line of treatment (topical) and second line of treatment(systemic), and enlist medications that have been successfully tested in the treatment of oral ulcers in Behcet's disease.

\section{Materials and Methods}

We began our search in Pub Med with a list of drugs used in the treatment of RAU including anesthetics such as lidocaine, benzocaine; antibiotics and antiseptics such as tetracycline, chlorhexidine, triclosan; corticosteroids such as triamcinolone, prednisolone, and dexamethosone; anti-inflammatory and antiallergic drugs such as amlexanox, 5aminosalicyclic acid, colchicines, hyaluronic acid; hemorrheologic agents such as pentoxifylline; zinc substitutes such as oral and systemic zinc sulphate; immunomodulatory agentssuch as cyclosporine,thalidomide, and interferon alpha; chemical cauterizing agent such as silver nitrate; and finally laser therapy. For retrieving the literature for each drug, we typed the name of the drug followed by the term aphthous, for example tetracycline aphthous, zinc sulphate aphthous, triamcinoloneaphthous.From the obtained list of publications, we selected only those publications that involved clinical trial of drugs related to RAU.

We also searched Pub Med using the term "Behcet's trial oral" and selected only those publications that described clinical trial with drugs on patients with Behcet's disease involving oral lesions. We reported the drug used, size of the patients sample, patient benefits, control for every drug, and the publication associated with the trial in a tabular form.

Our search with the terms "lidocaine aphthous" retrieved 19 publications, of which we selected two articles. Similarly, with the term "benzocaine apthous", total six publications were retrieved, of which we selected one article. We did not consider other articles, as they did not involve clinical trials on the drugs used for the treatment of aphthous ulcer.

Search with the term "tetracycline aphthous" retrieved 45 publications from which three articles discussing clinical trials of tetracycline were selected. Search with chlorhexidine aphthous retrieved 29 articles from which we chose five articles.

Similar searches were performed in Pub Med using the terms triclosan aphthous, triamcinolone aphthous, prednisolone aphthous, dexamethasone aphthous, amlexanox aphthous, 5-aminosalicylic acid, colchicines aphthous, hyaluronic acid, and pentoxifylline aphthous. The searches produced $3,43,95,22,20,6,86,5$, and 28 articles, respectively, for each drug of which 1, 4, 3, $2,8,1,5,4$, and 2 articles were selected, respectively.

We also searched for the terms "zinc sulphate aphthous" in Pub Med and obtained 6 articles, of which we selected four publications relevant to our systematic review. Search using the term "cyclosporine aphthous "produced 40 publications, but we could not find any publication that narrates clinical trials of cyclosporine on aphthous ulcer patients. However, search with the term "thalidomide aphthous "produced 178 publications, out of which we selected three publications. Search for immunomodulator interferon alpha aphthous resulted in 41 publications, out of which we selected two publications describing clinical trial.

Pub Med search on "silver nitrate aphthous" and "laser aphthous" produced 15 and 66 publications, 
respectively, of which 1 and 10 articles were chosen, respectively.

We searched the Pub Med using the term "Behcet's trial oral "and retrieved 86 publications, out of which we selected 20 publications.

\section{Results and Discussion}

Search results using the term aphthous with selected drugs and therapies belonging to different categories of drugs are described in Figs.1a, b, and 2.

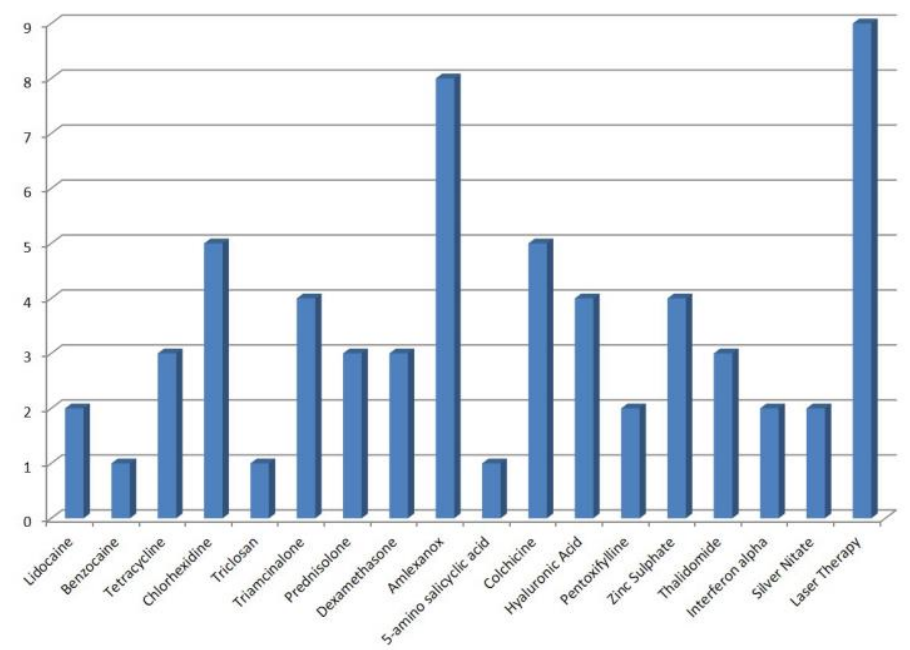

Fig. 1a: Number of clinical trials obtained by Pubmed searching for each drug category

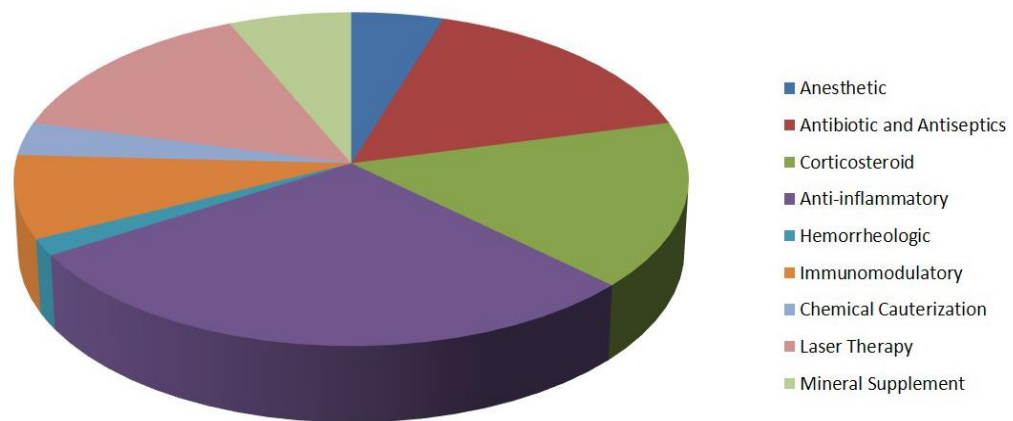

Fig. 1b: Representing largest and smallest number of drug clinical trials, obtained by searching Pubmed for drug categories

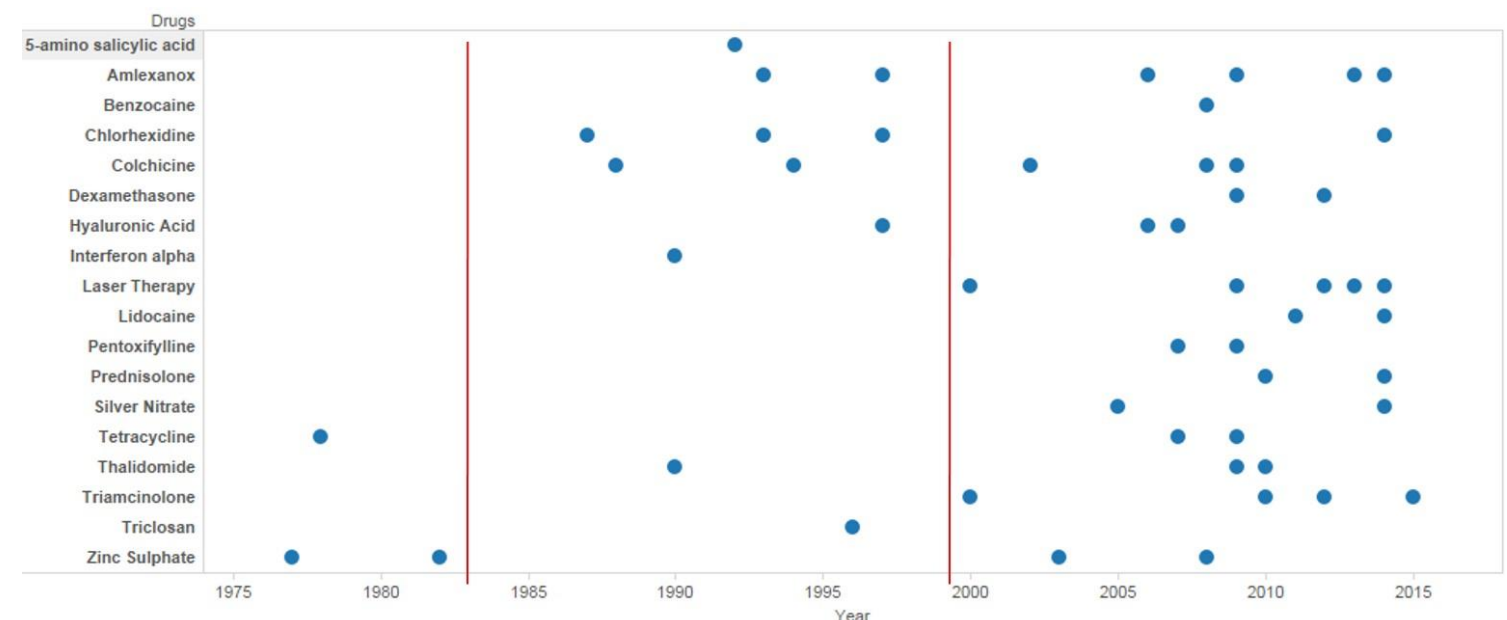

Fig. 2: Number of clinical trials conducted between 1975 and 2015 as enlisted by our search strategies 
Our results indicate that a large number of studies that we selected using the keywords aphthous followed by the name of the drug were conducted between 2000

and 2015 (Fig. 2). Some of the clinical trials were conducted without using a placebo whereas some of the research trials had compared the efficacy of one drug with another. Some researchers had used combined therapies to treat recurrent aphthous ulcers.

\section{Drug-drug comparison/combined therapy}

Out of 62 studies, 16 had performed comparative clinical trial and compared the effect of one drug with the other (Table 1).Also, few studies had used combined therapies to treat aphthous ulcers (Table 2). For example, study conducted by Sharda et al. ${ }^{35}$ compared the combined effect of levamisole and prednisolone with levamisole alone in treating aphthous ulcer; and the study by Saxen et al. ${ }^{54}$ compared the efficacy of hyaluronic acid and diclofenac combined with only hyaluronic acid.

Table 1: Drug-Drug Comparison

\begin{tabular}{|c|c|c|c|c|}
\hline Drug-Trial & $\begin{array}{c}\text { No of } \\
\text { Patients }\end{array}$ & Patient Benefits & $\begin{array}{c}\text { Placebo/Other Drugs } \\
\text { as Control }\end{array}$ & Publication \\
\hline Tetracycline & 17 & $\begin{array}{l}\text { More pain reduction and } \\
\text { less healing time with } \\
\text { minocycline }\end{array}$ & Minocycline & Gorsky $\mathrm{M}$ et al. ${ }^{22}$ \\
\hline Chlorhexidine & 70 & $\begin{array}{l}\text { More patients got healed } \\
\text { with Sucralfate }\end{array}$ & Sucralfate & SoyluÖzler G et al. ${ }^{25}$ \\
\hline Chlorhexidine & 30 & $\begin{array}{l}\text { No difference between } \\
\text { chlorhexidine and } \\
\text { triamcinolone treatment }\end{array}$ & Triamcinolone & Miles DA et al. ${ }^{26}$ \\
\hline Chlorhexidine & 18 & $\begin{array}{l}\text { No difference between } \\
\text { chlorhexidine and } \\
\text { benzydamine treatment }\end{array}$ & Benzydamine & Matthews RW et al. ${ }^{29}$ \\
\hline Triamcinolone & 60 & $\begin{array}{l}\text { More people using the } \\
\text { Eupatorium paste got } \\
\text { healed after } 5 \text { days. }\end{array}$ & $\begin{array}{l}\text { Eupatorium } \\
\text { laevigatum paste }\end{array}$ & Paulo Filho W et al. ${ }^{31}$ \\
\hline Triamcinolone & 56 & $\begin{array}{l}\text { The healing time was } \\
\text { less in the } \\
\text { Ageratinapichinchensis }\end{array}$ & $\begin{array}{l}\text { Extract of } \\
\text { Ageratinapichinchensis }\end{array}$ & $\begin{array}{l}\text { Romero-Cerecero } \mathrm{O} \text { et } \\
\text { al. }^{32}\end{array}$ \\
\hline Triamcinolone & 180 & $\begin{array}{l}\text { Reduction in ulcer size } \\
\text { and pain was more in } \\
\text { triamcinolone group }\end{array}$ & $0.5 \%$ Acemannan & Bhalang $\mathrm{K}$ et al. ${ }^{33}$ \\
\hline Triamcinolone & 20 & $\begin{array}{l}\text { Regression of lesion } \\
\text { happened earlier in the } \\
\text { laser group }\end{array}$ & $\begin{array}{l}\text { Low-level laser } \\
\text { therapy }\end{array}$ & De Souza TO et al. ${ }^{34}$ \\
\hline $\begin{array}{l}\text { Prednisolone } \\
\text { plus } \\
\text { Levamisole }\end{array}$ & 50 & $\begin{array}{l}\text { No difference between } \\
\text { prednisolone plus } \\
\text { levamisole treatment and } \\
\text { only levamisole } \\
\text { treatment }\end{array}$ & Levamisole & Sharda $\mathrm{N}$ et al. ${ }^{35}$ \\
\hline Prednisolone & 30 & $\begin{array}{l}\text { There was no difference } \\
\text { between prednisolone } \\
\text { treatment and colchicine } \\
\text { treatment }\end{array}$ & Colchicine & Pakfetrat A et al. ${ }^{36}$ \\
\hline Prednisolone & 60 & $\begin{array}{l}\text { Predisolone was more } \\
\text { effective than } \\
\text { montelukast in reducing } \\
\text { number of lesions and } \\
\text { pain. }\end{array}$ & Montelukast & Femiano $\mathrm{F}$ et al. $^{5}$ \\
\hline Dexamethasone & 90 & $\begin{array}{l}\text { Ulcer healing } \\
\text { significantly faster and } \\
\text { adverse effects reduced } \\
\text { as compared to } \\
\text { triamcinolone }\end{array}$ & Triamcinolone & Al-Na'mah ZM et al. ${ }^{38}$ \\
\hline
\end{tabular}




\begin{tabular}{|l|c|l|l|l|}
\hline Amlexanox 5\% & 100 & $\begin{array}{l}\text { Reduction in ulcer } \\
\text { number, size and } \\
\text { frequency of ulcer as } \\
\text { compared to antiseptic, } \\
\text { analgesic and anesthetic } \\
\text { paste }\end{array}$ & $\begin{array}{l}\text { Benzalkonium } \\
\text { chloride, choline } \\
\text { salicylate and lidocaine } \\
\text { hydrochloride }\end{array}$ & Darshan DD et al. $^{39}$ \\
\hline $\begin{array}{l}\text { Hyaluronic } \\
\text { acid }\end{array}$ & 60 & $\begin{array}{l}\text { There was more pain } \\
\text { reduction in the } \\
\text { diclofenac plus hyaluron } \\
\text { an compared to only } \\
\text { hyaluronan }\end{array}$ & $\begin{array}{l}\text { Hyaluronan plus } \\
\text { diclofenac }\end{array}$ & Saxen MA et al. $^{54}$ \\
\hline Zinc Sulphate & 45 & $\begin{array}{l}\text { Rapid and sustained } \\
\text { action of zinc sulphate } \\
\text { was observed }\end{array}$ & Dapsone, Glucose & Sharquie KE et al. ${ }^{58}$ \\
\hline Laser Therapy & 180 & $\begin{array}{l}\text { There were reduction in } \\
\text { pain intensity, erythema } \\
\text { and epithelization time }\end{array}$ & $\begin{array}{l}\text { Granofurin and } \\
\text { Solcoseryl }\end{array}$ & $\begin{array}{l}\text { Lalabonova H and } \\
\text { Daskalov H. }{ }^{69}\end{array}$ \\
\hline
\end{tabular}

Table 2: Combination therapy in aphthous ulcer

\begin{tabular}{|l|c|l|l|l|}
\hline $\begin{array}{l}\text { Prednisolone } \\
\text { plus Levamisole }\end{array}$ & 50 & $\begin{array}{l}\text { No difference between } \\
\text { prednisolone plus } \\
\text { levamisole treatment and } \\
\text { only levamisole treatment }\end{array}$ & Levamisole & Sharda N et al. ${ }^{35}$ \\
\hline Amlexanox 5\% & 100 & $\begin{array}{l}\text { Reduction in ulcer } \\
\text { number, size and } \\
\text { frequency of ulcer as } \\
\text { compared to antiseptic, } \\
\text { analgesic and anesthetic } \\
\text { paste }\end{array}$ & $\begin{array}{l}\text { Benzalkonium } \\
\text { chloride, choline } \\
\text { salicylate and lidocaine } \\
\text { hydrochloride }\end{array}$ & Darshan DD et al. ${ }^{39}$ \\
\hline Hyaluronic acid & 60 & $\begin{array}{l}\text { There was more pain } \\
\text { reduction in the diclofenac } \\
\text { plus hyaluron an } \\
\text { compared to only } \\
\text { hyaluronan }\end{array}$ & $\begin{array}{l}\text { Hyaluronan plus } \\
\text { diclofenac }\end{array}$ & Saxen MA et al. ${ }^{54}$ \\
\hline Laser Therapy & 180 & $\begin{array}{l}\text { There were reduction in } \\
\text { pain intensity, erythema } \\
\text { and epithelization time }\end{array}$ & $\begin{array}{l}\text { Granofurin and } \\
\text { Solcoseryl }\end{array}$ & Lalabonova H and \\
Daskalov H. ${ }^{69}$
\end{tabular}

\section{Studies with large sample size}

In the selected list of publications, several cases involved a considerably large sample of patients. Study on the effect of laser therapy by Lalabonova ${ }^{69}$ involved 180 patients, study on the effect of hyaluronic acid involved 180 patients, and a clinical trial performed by Liu $\mathrm{C}$ et al. ${ }^{37}$ to check the efficacy of dexamethasone involved a total of 240 patients. To know the effectiveness of amlexanox in healing aphthous ulcers, Binnie et al. ${ }^{44}$ and Khandwala et al. ${ }^{45}$ recruited more than 1000 patients.

\section{Measuring end points}

Many studies among the selected list of publications had used pain scale measurement as one of the endpoints in their clinical trial. Two types of pain scales were used: (a) one-dimensional pain scales such as visual analog scale (VAS) and numerical rating scale (NRS) and (b) multidimensional pain scale such as brief pain inventory (BPI). Most of the studies reported decrease in the severity of pain as a result of their selected interventions. Some studies including that of Alidaee et al. ${ }^{67}$ reported decrease in pain level but not in shortening of healing time as a result of application of silver nitrate.

Several studies had measured ulcer size as one of the endpoints. Study by Darshan et al. ${ }^{39}$ reported the frequency of ulcer development; however, Liu et al. ${ }^{42}$, Bhat et al. ${ }^{40}$, Greer et al. ${ }^{46}$ and Lalabonova ${ }^{69}$ reported reduction of erythema. Interestingly, some of the selected clinical studies reported complete remission or no reappearance of aphthous ulcers. Studies belonging 
to this group are the clinical trials performed by Mimura et al. ${ }^{48}$ with pentoxifylline, study by Orbak et al. ${ }^{59}$ with zinc sulphate, Hello et al. ${ }^{62}$ with thalidomide, Hutchinson et al. ${ }^{65}$ with interferon alpha, and Aggarwal et al. ${ }^{71}$ with laser therapy.

\section{Differences observed in the studies}

Among the comparative studies on aphthous ulcer from the selected list of publications, some studies did not find any significant difference between the interventions used (Table 3). For example, Miles et al. $^{26}$ did not find any significant difference between chlorhexidine and triamcinalone treatment, Matthews et al. $^{29}$ did not report any difference between chlorhexidine and benzydamine treatment, and Sharda et.al. ${ }^{35}$ did not find any difference between levamisole and levamisole plus prednisolone treatment. Lastly, no difference was observed between colchicine and prednisolone treatment in a study by Pakftrat et al. ${ }^{36}$

Table 3: Differences observed between two therapies

\begin{tabular}{|l|c|l|c|c|}
\hline \multicolumn{1}{|c|}{ Drug-Trial } & $\begin{array}{c}\text { No of } \\
\text { Patients }\end{array}$ & \multicolumn{1}{|c|}{ Patient Benefits } & $\begin{array}{c}\text { Placebo/Other } \\
\text { Drugs as Control }\end{array}$ & Publication \\
\hline Chlorhexidine & 30 & $\begin{array}{l}\text { No difference between } \\
\text { chlorhexidine and } \\
\text { triamcinolone treatment }\end{array}$ & Triamcinolone & Miles DA et al. ${ }^{26}$ \\
\hline Chlorhexidine & 18 & $\begin{array}{l}\text { No difference between } \\
\text { chlorhexidine and } \\
\text { benzydamine treatment }\end{array}$ & Benzydamine & Matthews RW et al. $^{29}$ \\
\hline $\begin{array}{l}\text { Prednisolone } \\
\text { plus Levamisole }\end{array}$ & 50 & $\begin{array}{l}\text { No difference between } \\
\text { prednisolone plus } \\
\text { levamisole treatment and } \\
\text { only levamisole treatment }\end{array}$ & Levamisole & Sharda N et al. $^{35}$ \\
\hline Prednisolone & 30 & $\begin{array}{l}\text { There was no difference } \\
\text { between prednisolone } \\
\text { treatment and colchicine } \\
\text { treatment }\end{array}$ & Colchicine & Pakfetrat A et al. $^{36}$ \\
\hline
\end{tabular}

\section{Superiority of one treatment over others}

Several studies among the selected list of publications showed superiority of one intervention to another (Table 4). For example, mucoadhesive patch was superior to benzocaine, ${ }^{21}$ minocycline was superior to tetracycline, ${ }^{22}$ sucralfate was superior to chlorhexidine $^{25}$, triamcinolone was superior to $5 \%$ acemannan, ${ }^{33}$ and laser therapy was better than triamcinolone. ${ }^{34}$

Table 4: Comparison of superiority of one treatment over another

\begin{tabular}{|c|c|c|c|c|}
\hline Drug-Trial & $\begin{array}{c}\text { No of } \\
\text { Patients }\end{array}$ & Patient Benefits & $\begin{array}{c}\text { Placebo/Other } \\
\text { Drugs as Control }\end{array}$ & Publication \\
\hline Benzocaine & 48 & $\begin{array}{l}\text { More pain reduction and less } \\
\text { healing time with } \\
\text { mucoadhesive patch. }\end{array}$ & Mucoadhesive Patch & Shemer A et al. ${ }^{21}$ \\
\hline Tetracycline & 17 & $\begin{array}{l}\text { More pain reduction and less } \\
\text { healing time with } \\
\text { minocycline }\end{array}$ & Minocycline & Gorsky $\mathrm{M}$ et al. $^{22}$ \\
\hline Chlorhexidine & 70 & $\begin{array}{l}\text { More patients got healed } \\
\text { with Sucralfate }\end{array}$ & Sucralfate & $\begin{array}{l}\text { SoyluÖzler G et } \\
\text { al. }{ }^{25}\end{array}$ \\
\hline Triamcinolone & 180 & $\begin{array}{l}\text { Reduction in ulcer size and } \\
\text { pain was more in } \\
\text { triamcinolone group }\end{array}$ & $0.5 \%$ Acemannan & Bhalang K et al. ${ }^{33}$ \\
\hline Triamcinolone & 20 & $\begin{array}{l}\text { Regression of lesion } \\
\text { happened earlier in the laser } \\
\text { group }\end{array}$ & $\begin{array}{l}\text { Low-level laser } \\
\text { therapy }\end{array}$ & $\begin{array}{l}\text { De Souza TO et } \\
\text { al. }{ }^{34}\end{array}$ \\
\hline
\end{tabular}

\section{Retrospective and prospective studies}

A few retrospective studies had been enlisted in our study. Studies by Lynde et al., ${ }^{49}$ Hello et al., ${ }^{62}$ and
Gil et al. ${ }^{63}$ were retrospective in nature. Prospective and retrospective studies had both strength and weaknesses. The major strength of a prospective cohort study was 
the accuracy of data collection with regard to exposures, confounders, and endpoints. This approach was both expensive and time consuming because of long follow-up period. The retrospective design was very time efficient and new questions were answered with the existing data. However, one has no choice other than to work with what has been measured in the past.

Immunomodulators/phosphodiesterase inhibitors in treating oral lesions associated with Behcet's disease

Behcet's syndrome is associated with lesions in multiple organs including the skin, mouth, intestine, and eye. The first line of therapy is corticosteroid and immunomodulatory agents followed by TNF-blocking agents. In our review, we report several clinical trials involving various therapeutic agents. The outcome measures of the clinical trials may involve measurements associated with genital ulcers, skin lesions, or uveitis; however, we have solely reported outcomes associated with oral lesions. One of the interesting finding was the clinical trial by Kotter et al. ${ }^{88}$ which describes significant reduction in genital and skin lesions, and oral ulcers by interferon-alpha. Cyclosporine has been stated to be more effective than colchicines in reducing oral apthae as reported by Masuda et al. ${ }^{95}$ Interestingly, azithromycin has been shown to reduce oral lesions in Behcet's syndrome by Mumcu et al.; ${ }^{84}$ however, antiviral agent acyclovir has no effect on Behcet's disease as reported by Davies et al. ${ }^{96}$ Tanida et al. ${ }^{85}$ reported complete remission of oral ulcers by adalimumab, which is a TNF-inhibiting antiinflammatory agent. Apart from the immunomodulatory agents, phosphodiesterase inhibitors have also shown promise in reducing aphthous ulcer in patients with Behcet's syndrome. Clinical trials conducted by Nanke et al. ${ }^{86}$ onirsogladineand Hatemi et al. ${ }^{78}$ on aprimilast provide evidence on the efficiency of phosphodiesterse inhibitors.

Based on the results of our systematic review we have enlisted certain drugs, which may be used in the first- and the second-line therapy for RAU (Tables 5 and 6).

Table 5: List of drugs and dosages to be used in first line of therapy for minor RAU

\begin{tabular}{|l|l|l|c|}
\hline \multicolumn{1}{|c|}{$\begin{array}{c}\text { First Line of } \\
\text { Treatment }\end{array}$} & \multicolumn{1}{|c|}{ Class of Drug } & Dosage & Duration \\
\hline Sucralfate & Oral-Local & $\begin{array}{l}\text { Topical 10\% sucralfate } \\
\text { solution }\end{array}$ & 3 months \\
\hline Minocycline & Antibiotic & $0.2 \%$ minocycline mouthwash & 10 days \\
\hline $\begin{array}{l}\text { Hyaluronic Acid } \\
\text { plus Diclofenac }\end{array}$ & Anti-inflammatory & $\begin{array}{l}3 \% \text { Diclofenac in } 2.5 \% \\
\text { Hyaluronan }\end{array}$ & 8 hours \\
\hline Dexamethasone & Corticosteroid & Oral Paste0.1\% & 14 days \\
\hline Amlexanox & Anti-Inflammatory & $5 \%$ Amlexanox oral paste & 4 days \\
\hline Low level Laser & Light Therapy & $\begin{array}{l}\text { Output power of 0.5 W and a } \\
\text { Wavelength of } 810 \mathrm{~nm}\end{array}$ & 7 days \\
\hline
\end{tabular}

Table 6: List of drugs and dosages to be used in second line of therapy for major refractory aphthae

\begin{tabular}{|c|c|c|c|}
\hline $\begin{array}{l}\text { Second Line of } \\
\text { Treatment(For } \\
\text { major refractory } \\
\text { aphthous ulcer) }\end{array}$ & Class of Drug & Systemic Dosage & Duration \\
\hline Colchicine & $\begin{array}{l}\text { Secondary } \\
\text { Metabolite/Natural } \\
\text { Product }\end{array}$ & $1.5 \mathrm{mg} / \mathrm{day}$ & 1 year \\
\hline Prednisolone & Synthetic Glucocorticoid & $25 \mathrm{mg} /$ day & 15 days \\
\hline Interferon alpha & Biological therapy & $\begin{array}{l}6 \text { million IU-3 times } \\
\text { weekly }\end{array}$ & 3 months \\
\hline Adalimumab & $\begin{array}{l}\text { Therapeutic monoclonal } \\
\text { antibody(TNF alpha } \\
\text { inhibitor) }\end{array}$ & $\begin{array}{l}160 \mathrm{mg} \text { on the first } \\
\text { day, } 80 \mathrm{mg} \text { two } \\
\text { weeks later and } \\
40 \mathrm{mg} \text { alternate } \\
\text { weeks for } 52 \text { weeks. }\end{array}$ & 54 weeks \\
\hline Ethanercept & $\begin{array}{l}\text { Biopharmaceutical (TNF } \\
\text { alpha inhibitor) }\end{array}$ & $25 \mathrm{mg}$ twice a week & 4 weeks \\
\hline Apremilast & $\begin{array}{l}\text { Phosphodiesterase } 4 \\
\text { inhibitor }\end{array}$ & $\begin{array}{l}\text { 30mg Apremilast } \\
\text { twice daily }\end{array}$ & 12 weeks \\
\hline Irsogladine & $\begin{array}{l}\text { Phosphodiesterase } \\
\text { inhibitor }\end{array}$ & 2-4 mg/day & 3 months \\
\hline
\end{tabular}




\section{Comparison of several drugs used in first line of treatment \\ Use of sucralfate}

Topical medication is definitely the first-line of treatment in oral aphthous ulcer followed by systemic therapy. Belenguer-Guallar et al., ${ }^{18}$ suggested that several drugs including chlorhexidine, triclosan, hyaluronic acid, benzydamine,doxycycline, and amlexanox. sucralfate healed more number of patients with aphthous ulcer than chlorhexidine (SoyluOzler et al. ${ }^{25}$ ). It should be noted that sucralfate is routinely used in the treatment of gastrointestinal ulcers, duodenal ulcers, stress-related ulcers, and aphthous ulcers resulting from chemotherapy and radiotherapy.

\section{Use of minocycline}

A study by Alpsoy et al. ${ }^{91}$ showed the efficacy of sucralfate in reducing oral ulcers in Behcet's disease. Belenguer-Guallar et al., ${ }^{18}$ suggested the use of doxycycline. However, minocycline can be more effective than doxycyline ${ }^{22}$ as it has broader spectrum of action as compared to other tetracycline drugs.

\section{Use of hyaluronic acid plus diclofenac}

If the medical practitioner wishes to prescribe hyaluronic acid, a combination of hyaluronic acid and diclofenac is suggested. ${ }^{54}$ Belenguer-Guallar et al. has described the use of anti-inflammatory drug amlexanox in the early phase of the disease, as several clinical trials have confirmed the effectiveness of amlexanox in treating recurrent aphthous ulcer. ${ }^{41-45}$

\section{Use of laser therapy}

In the first-line of therapy, involving topical corticosteroids, Belenguer-Guallar et al. suggested the use of three drugs triamcinolone acetonide, fluocinoloneacetonide or clobetasol propionate. Clinical trials have shown low level laser therapy to be more effective as compared to triamcinolone. ${ }^{34}$

\section{Comparison of several drugs used in second line of treatment \\ Use of colchicine}

Second line of therapy involving systemic corticosteroids and immunomodulators are prescribed very severe and are refractory recurrent oral ulcers. Belenguer-Guallar et al., ${ }^{18}$ mentioned the use of drugs such as pentoxifylline, colchicine, dapsone, and thalidomide in treating severe aphthous ulcer. Use of corticosteroid prednisolone was also suggested as one of the treatment options in severe aphthosis. However, according to Pakfetratet al. $^{36}$ no difference was observed between prednisolone and colchicines in treatment of aphthous ulcer. Lynde et al. ${ }^{49}$ and Fontes et al..$^{50}$ recommendedcolchicine treatment in patients with severe and complex aphthous. According to Lynde etal. colchicine is safe and effective without any serious side effect supported by the data of more than 50 patients treated at Mayo Clinic, USA between 1998 and 2007. Apart from this article, a study by Fontes et al., in a follow up study with colchicine for more than 4 years, also recommended colchicine as preventive therapy in severe recurrent stomatitis.

\section{Use of interferon alpha}

Hutchinson et al. ${ }^{66}$ reported complete remission of major aphthae in two patients when interferon-alpha was administered. Alpsoy et al. ${ }^{90}$ Hamuryudan et al. ${ }^{94}$ and O'Duffy et al. ${ }^{92}$ observed effectiveness of interferon-alpha in the treatment of oral ulcers in Behcet's disease. Although thalidomide is an effective treatment for severe aphthous ulcer (Hello $\mathrm{M}$ et al ${ }^{62}$ ), Belenguer-Guallar et al. has mentioned about its potential side effects.

Use of adalimumab, etanercept, aprelimast, and irsogladine in treatment of oral lesions in Behcet's disease

Clinical trials involving adalimumab, an inhibitor of TNF-alpha, performed on patients with Behcet's disease showed its effectiveness in completely eradicating oral aphthous ulcer in two-third of the total patients (Tanida et al. ${ }^{85}$ ). Although there are case reports on effectiveness of adalimumab in treating major recalcitrant oral aphthous ulcers, there is no report of clinical trial with the drug in patients withmajor aphthae. Adalimumab may be a potential therapy in patients with major aphthous ulcer. Another inhibitor of TNF-alpha, etanercept, has also been effective in suppressing oral ulcers in Behcet's disease ${ }^{87}$ There are a few case reports on the drug in recalcitrant major aphthae, but no comprehensive clinical trial has been reported. There is another class of drug called phosphodiesterase inhibitors type 4 (PDE4), which inhibits the activities of TNF. Clinical trials with PDE4 inhibitors - aprelimast and irsogladine performed by Hatemi et al. ${ }^{78}$ and Nanke et al. ${ }^{86}$ reported effective treatment of oral ulcers in patients with Behcet's. A well-designed clinical trial is recommended for these drugs in major oral refractory aphthous ulcer patients.

To summarise, we have compared different treatment options for patients suffering from RAU and major refractory oral aphthae, and discussed the suggestions by Belenguer-Guallar et $\mathrm{al}^{18}$ about the drugs and therapies along with their dosages, which may be used in the first-line of treatment (topical) and secondline of treatment (systemic). Also, the selected medications, which have been successfully tested in oral ulcer in Behcet's disease, are discussed. The 
limitations of this study is we have not considered other systemic conditions and syndromes which has RAU as its component except Bechet's syndrome. An extensive review with the above inclusions would be better in understanding the efficacy of drugs (both topical and systemic) in treating RAU and RAU associated conditions.

\section{Conclusion}

Novel research strategies should be designed to clinically test combination therapies in the treatment of aphthous ulcer. Drugs that are clinically effective and have cured aphthous ulcers in large number of patients may be used. Further research may be carried out to understand the effectiveness of immunomodulators and phosphodiesterase inhibitors in the treatment of major recalcitrant aphthous ulcer and oral lesions associated with Behcet's disease.

\section{References}

1. Chavan M, Jain H, Diwan N, Khedkar S, Shete A, Durkar S. Recurrent aphthous stomatitis: a review. J Oral Pathol Med 2012; 41:577-583.

2. Preeti L, Magesh K, Rajkumar K, Karthik R. Recurrent aphthous stomatitis. J Oral Maxillofac Pathol 2011;15:252-256.

3. Zhou Y, Chen Q, Meng W, Jiang L, Wang Z, Liu J et al. Evaluation of penicillin $\mathrm{G}$ potassium troches in the treatment of minor recurrent aphthous ulceration in a Chinese cohort: a randomized, double-blinded, placebo and no-treatment-controlled, multicenter clinical trial. Oral Surg Oral Med Oral Pathol Oral Radiol Endod 2010;109:561-566.

4. Quijano D, Rodriguez M. Topical corticosteroids in recurrent aphthous stomatitis. Systematic review. Acta Otorrinolaringol Esp 2008;59:298-307.

5. Femiano F, Buonaiuto C, Gombos F, Lanza A, Cirillo N. Pilot study on recurrent aphthous stomatitis (RAS): a randomized placebo-controlled trial for the comparative therapeutic effects of systemic prednisone and systemic montelukast in subjects unresponsive to topical therapy. Oral Surg Oral Med Oral Pathol Oral Radiol Endod 2010;109:402-407.

6. Liang MW, Neoh CY. Oral aphthosis: management gaps and recent advances. Ann Acad Med Singapore 2012;41:463-470.

7. Scully C, Porter S. Oral mucosal disease: recurrent aphthous stomatitis. Br J Oral Maxillofac Surg 2008;46:198-206.

8. Altenburg A, Krahl D, Zouboulis CC. Non-infectious ulcerating oral mucous membrane diseases. J Dtsch Dermatol Ges 2009;7:242-257.

9. Schroeder HE, Muller-Glauser W, Sallay K. Stereologic analysis of leukocyte infiltration in oral ulcers of developing Mikulicz aphthae. Oral Surg Oral Med Oral Pathol 1983;56:629-640.

10. Bruce AJ, Rogers RS, 3rd. Acute oral ulcers. Dermatol Clin 2003;21:1-15.

11. Fox EC. The problem or oral ulcerations in general practice with special reference to herpetic herpetiform lesions. J R Coll Gen Pract 1970;19:191-200.

12. Akintoye SO, Greenberg MS. Recurrent aphthous stomatitis. Dent Clin North Am 2014;58:281-297.

13. Keogan MT. Clinical Immunology Review Series: an approach to the patient with recurrent orogenital ulceration, including Behcet's syndrome. Clin Exp Immunol 2009;156:1-11.

14. Krause I, Uziel Y, Guedj D, Mukamel M, Molad Y, Amit $\mathrm{M}$ et al. Mode of presentation and multisystem involvement in Behcet's disease: the influence of sex and age of disease onset. J Rheumatol 1998;25:1566-1569.

15. Krause I, Rosen Y, Kaplan I, Milo G, Guedj D, Molad Y et al. Recurrent aphthous stomatitis in Behcet's disease: clinical features and correlation with systemic disease expression and severity. J Oral Pathol Med 1999;28:193196.

16. Krause I, Monselise Y, Milo G, Weinberger A. AntiSaccharomyces cerevisiae antibodies--a novel serologic marker for Behcet's disease. Clin Exp Rheumatol 2002;20:S21-24.

17. Altenburg A, El-Haj N, Micheli C, Puttkammer M, Abdel-Naser MB, Zouboulis CC. The treatment of chronic recurrent oral aphthous ulcers. Dtsch ArzteblInt 2014;111:665-673.

18. Belenguer-Guallar I, Jimenez-Soriano Y, ClaramuntLozano A. Treatment of recurrent aphthous stomatitis. A literature review. J Clin Exp Dent 2014;6:e168-174.

19. Coudert AE, Ostertag A, Baaroun V, Artaud C, Ifi-Naulin $\mathrm{C}$, Druo JP et al. Phase III, randomized, double-blind, placebo-controlled trial of topical $2 \%$ lidocaine for the prevention and treatment of oral mucosal pain in children. Clin Oral Investig 2014;18:1189-1194.

20. Descroix V, Coudert AE, Vige A, Durand JP, Toupenay S, Molla M et al. Efficacy of topical $1 \%$ lidocaine in the symptomatic treatment of pain associated with oral mucosal trauma or minor oral aphthous ulcer: a randomized, double-blind, placebo-controlled, parallelgroup, single-dose study. J Orofac Pain 2011;25:327-332.

21. Shemer A, Amichai B, Trau H, Nathansohn N, Mizrahi B, Domb AJ. Efficacy of a mucoadhesive patch compared with an oral solution for treatment of aphthous stomatitis. Drugs R D 2008;9:29-35.

22. Gorsky M, Epstein J, Rabenstein S, Elishoov H, Yarom $\mathrm{N}$. Topical minocycline and tetracycline rinses in treatment of recurrent aphthous stomatitis: a randomized cross-over study. Dermatol Online J 2007;13:1.

23. Skulason S, Holbrook WP, Kristmundsdottir T. Clinical assessment of the effect of a matrix metalloproteinase inhibitor on aphthous ulcers. ActaOdontolScand 2009;67:25-29.

24. Graykowski EA, Kingman A. Double-blind trial of tetracycline in recurrent aphthous ulceration. J Oral Pathol 1978;7:376-382.

25. SoyluOzler G, Okuyucu S, Akoglu E. The Efficacy of Sucralfate and Chlorhexidine as an Oral Rinse in Patients with Recurrent Aphthous Stomatitis. Adv Med 2014;2014:986203.

26. Miles DA, Bricker SL, Razmus TF, Potter RH. Triamcinolone acetonide versus chlorhexidine for treatment of recurrent stomatitis.Oral Surg Oral Med Oral Pathol 1993;75:397-402.

27. Addy M, Hunter L. The effects of a $0.2 \%$ chlorhexidine gluconate mouthrinse on plaque, toothstaining and candida in aphthous ulcer patients.A double-blind placebo-controlled cross-over study.J Clin Periodontol 1987;14:267-273.

28. Edres MA, Scully C, Gelbier M. Use of proprietary agents to relieve recurrent aphthous stomatitis. Br Dent J 1997;182:144-146.

29. Matthews RW, Scully CM, Levers BG, Hislop WS.Clinical evaluation of benzydamine, chlorhexidine, and placebo mouthwashes in the management of 
recurrent aphthous stomatitis.Oral Surg Oral Med Oral Pathol 1987;63:189-191.

30. Skaare AB, Herlofson BB, Barkvoll P. Mouthrinses containing triclosan reduce the incidence of recurrent aphthous ulcers (RAU). J Clin Periodontol 1996;23:778781.

31. Paulo Filho W, Ribeiro JE, Pinto DS. Safety and efficacy of Eupatorium laevigatum paste as therapy for buccal aphthae: randomized, double-blind comparison with triamcinolone $0.1 \%$ orabase. Adv Ther 2000; 17:272-281.

32. Romero-Cerecero O, Zamilpa A, Tortoriello J. Pilot study that evaluated the clinical effectiveness and safety of a phytopharmaceutical elaborated with an extract of Ageratinapichinchensis in patients with minor recurrent aphthous stomatitis. J Ethnopharmacol 2015;173:225230.

33. Bhalang K, Thunyakitpisal P, Rungsirisatean N. Acemannan, a polysaccharide extracted from Aloe vera, is effective in the treatment of oral aphthous ulceration. J Altern Complement Med 2013;19:429-434.

34. De Souza TO, Martins MA, Bussadori SK, Fernandes KP, Tanji EY, Mesquita-Ferrari RA et al. Clinical evaluation of low-level laser treatment for recurring aphthous stomatitis. Photomed Laser Surg 2010;28Suppl 2:S85-88.

35. Sharda N, Shashikanth MC, Kant P, Jain M. Levamisole and low-dose prednisolone in the treatment of reccurentaphthous stomatitis. J Oral Pathol Med 2014;43:309-316.

36. Pakfetrat A, Mansourian A, Momen-Heravi F, Delavarian Z, Momen-Beitollahi J, Khalilzadeh O et al. Comparison of colchicine versus prednisolone in recurrent aphthous stomatitis: A double-blind randomized clinical trial. Clin Invest Med 2010;33:E189-195.

37. Liu C, Zhou Z, Liu G, Wang Q, Chen J, Wang L et al. Efficacy and safety of dexamethasone ointment on recurrent aphthous ulceration. Am J Med 2012;125:292301

38. Al-Na'mah ZM, Carson R, Thanoon IA. Dexamucobase: a novel treatment for oral aphthous ulceration. Quintessence Int 2009;40:399-404.

39. Darshan DD, Kumar CN, Kumar AD, Manikantan NS, Balakrishnan D, Uthkal MP.Clinical study to know the efficacy of Amlexanox 5\% with other topical Antiseptic, Analgesic and Anesthetic agents in treating minor RAS. J Int Oral Health 2014;6:5-11.

40. Bhat S, Sujatha D. A clinical evaluation of $5 \%$ amlexanox oral paste in the treatment of minor recurrent aphthous ulcers and comparison with the placebo paste: a randomized, vehicle controlled, parallel, single center clinical trial. Indian J Dent Res 2013;24:593-598.

41. Meng W, Dong Y, Liu J, Wang Z, Zhong X, Chen R et al. A clinical evaluation of amlexanox oral adhesive pellicles in the treatment of recurrent aphthous stomatitis and comparison with amlexanox oral tablets: a randomized, placebo controlled, blinded, multicenter clinical trial. Trials 2009;10:30.

42. Liu J, Zeng X, Chen Q, Cai Y, Chen F, Wang Y et al. An evaluation on the efficacy and safety of amlexanox oral adhesive tablets in the treatment of recurrent minor aphthous ulceration in a Chinese cohort: a randomized, double-blind, vehicle-controlled, unparallel multicenter clinical trial. Oral Surg Oral Med Oral Pathol Oral Radiol Endod 2006;102:475-481.

43. Murray B, Biagioni PA, Lamey PJ. The efficacy of amlexanox OraDisc on the prevention of recurrent minor aphthous ulceration. J Oral Pathol Med 2006;35:117-122.
44. Binnie WH, Curro FA, Khandwala A, Van Inwegan RG. Amlexanox oral paste: a novel treatment that accelerates the healing of aphthous ulcers. Compend Contin Educ Dent 1997;18:1116-1118,1120-1112,1124 passim.

45. Khandwala A, Van Inwegen RG, Alfano MC. 5\% amlexanox oral paste, a new treatment for recurrent minor aphthous ulcers: I. Clinical demonstration of acceleration of healing and resolution of pain. Oral Surg Oral Med Oral Pathol Oral Radiol Endod 1997;83:222230.

46. Greer RO, Jr., Lindenmuth JE, Juarez T, Khandwala A.A double-blind study of topically applied 5\% amlexanox in the treatment of aphthous ulcers.J Oral Maxillofac Surg 1993; 51:243-248.

47. Collier PM, Neill SM, Copeman PW. Topical 5aminosalicylic acid: a treatment for aphthous ulcers. Br J Dermatol 1992;126:185-188.

48. Mimura MA, Hirota SK, Sugaya NN, Sanches Jr JA, Migliari DA. Systemic treatment in severe cases of recurrent aphthous stomatitis: an open trial. Clinics (Sao Paulo) 2009;64:193-198.

49. Lynde CB, Bruce AJ, Rogers RS, 3rd. Successful treatment of complex aphthosis with colchicine and dapsone. Arch Dermatol 2009;145:273-276.

50. Fontes V, Machet L, Huttenberger B, Lorette G, Vaillant L. Recurrent aphthous stomatitis: treatment with colchicine. An open trial of 54 cases. Ann Dermatol Venereol 2002;129:1365-1369.

51. Katz J, Langevitz P, Shemer J, Barak S, Livneh A. Prevention of recurrent aphthous stomatitis with colchicine: an open trial. J Am Acad Dermatol 1994;31:459-461.

52. Ruah CB, Stram JR, Chasin WD. Treatment of severe recurrent aphthous stomatitis with colchicine. Arch Otolaryngol Head Neck Surg 1988;114:671-675.

53. Nolan A, Baillie C, Badminton J, Rudralingham M, Seymour RA. The efficacy of topical hyaluronic acid in the management of recurrent aphthous ulceration. J Oral Pathol Med 2006;35:461-465.

54. Saxen MA, Ambrosius WT, Rehemtula al KF, Russell AL, Eckert GJ. Sustained relief of oral aphthous ulcer pain from topical diclofenac in hyaluronan: a randomized, double-blind clinical trial. Oral Surg Oral Med Oral Pathol Oral Radiol Endod 1997;84:356-361.

55. Porter S. Transient benefits for topical hyaluronic acid in recurrent aphthous ulceration. Evid Based Dent 2007;8:52.

56. Lee JH, Jung JY, Bang D. The efficacy of topical $0.2 \%$ hyaluronic acid gel on recurrent oral ulcers: comparison between recurrent aphthous ulcers and the oral ulcers of Behcet's disease. J Eur Acad Dermatol Venereol 2008;22:590-595.

57. Thornhill MH, Baccaglini L, Theaker E, Pemberton MN. A randomized, double-blind, placebo-controlled trial of pentoxifylline for the treatment of recurrent aphthous stomatitis. Arch Dermatol 2007;143:463-470.

58. Sharquie KE, Najim RA, Al-Hayani RK, Al-Nuaimy AA, Maroof DM.The therapeutic and prophylactic role of oral zinc sulfate in management of recurrent aphthous stomatitis (ras) in comparison with dapsone. Saudi Med J 2008;29:734-738.

59. Orbak R, Cicek Y, Tezel A, Dogru Y. Effects of zinc treatment in patients with recurrent aphthous stomatitis. Dent Mater J 2003;22:21-29.

60. Wray D.A double-blind trial of systemic zinc sulfate in recurrent aphthous stomatitis.Oral Surg Oral Med Oral Pathol 1982;53:469-472. 
61. Merchant HW, Gangarosa LP, Glassman AB, Sobel RE. Zinc sulfate supplementation for treatment of recurring oral ulcers.South Med J 1977;70:559-561.

62. Hello M, Barbarot S, Bastuji-Garin S, Revuz J, Chosidow O. Use of thalidomide for severe recurrent aphthous stomatitis: a multicenter cohort analysis. Medicine (Baltimore) 2010;89:176-182.

63. Gil H, Perrin S, Dupond JL, Meaux-Ruault N, Hafsaoui C, Limat S et al. [Recurrent aphthosis: safety of low dose thalidomide]. Rev Med Interne 2010;31:403-405.

64. Revuz J, Guillaume JC, Janier M, Hans P, Marchand C, Souteyrand $\mathrm{P}$ et al. Crossover study of thalidomide vs placebo in severe recurrent aphthous stomatitis. Arch Dermatol 1990;126:923-927.

65. Hutchinson VA, Angenend JL, Mok WL, Cummins JM, Richards AB. Chronic recurrent aphthous stomatitis: oral treatment with low-dose interferon alpha. Mol Biother 1990;2:160-164.

66. Hutchinson VA, Mok WL, Angenend JL, Cummins JM, Richards AB. Chronic major aphthous stomatitis: oral treatment with low-dose alpha-interferon. Mol Biother 1990;2:217-220.

67. Alidaee MR, Taheri A, Mansoori P, Ghodsi SZ. Silver nitrate cautery in aphthous stomatitis: a randomized controlled trial. Br J Dermatol 2005;153:521-525.

68. SoyluOzler G. Silver nitrate cauterization: a treatment option for aphthous stomatitis. J Craniomaxillofac Surg 2014;42:e281-283

69. Lalabonova H, Daskalov H. Clinical assessment of the therapeutic effect of low-level laser therapy on chronic recurrent aphthous stomatitis. Biotechnol Biotechnol Equip 2014;28:929-933.

70. Albrektson M, Hedstrom L, Bergh H. Recurrent aphthous stomatitis and pain management with low-level laser therapy: a randomized controlled trial. Oral Surg Oral Med Oral Pathol Oral Radiol 2014;117:590-594.

71. Aggarwal H, Singh MP, Nahar P, Mathur H, Gv S. Efficacy of low-level laser therapy in treatment of recurrent aphthous ulcers - a sham controlled, split mouth follow up study. J Clin Diagn Res 2014;8:218-221.

72. Sattayut S, Trivibulwanich J, Pipithirunkarn N, Danvirutai N. A clinical efficacy of using $\mathrm{CO} 2$ laser irradiating to transparent gel on aphthous stomatitis patients. Laser Ther 2013;22:283-289.

73. Prasad RS, Pai A. Assessment of immediate pain relief with laser treatment in recurrent aphthous stomatitis. Oral Surg Oral Med Oral Pathol Oral Radiol 2013;116:189193.

74. Zand N, Fateh M, Ataie-Fashtami L, Djavid GE, Fatemi SM, Shirkavand A. Promoting wound healing in minor recurrent aphthous stomatitis by non-thermal, nonablative $\mathrm{CO}(2)$ laser therapy: a pilot study. Photomed Laser Surg 2012;30:719-723.

75. Tezel A, Kara C, Balkaya V, Orbak R. An evaluation of different treatments for recurrent aphthous stomatitis and patient perceptions: Nd:YAG laser versus medication. Photomed Laser Surg 2009;27:101-106.

76. Zand N, Ataie-Fashtami L, Djavid GE, Fateh M, Alinaghizadeh MR, Fatemi SM et al. Relieving pain in minor aphthous stomatitis by a single session of nonthermal carbon dioxide laser irradiation. Lasers Med Sci 2009;24:515-520.

77. Prikuls VF. Experience in irradiating with helium-neon lasers to treat patients with relapsing aphthous stomatitis.Stomatologiia (Mosk) 2000;79:20-22.

78. Hatemi G, Melikoglu M, Tunc R, Korkmaz C, TurgutOzturk B, Mat C et al. Apremilast for Behcet's syndrome--a phase 2, placebo-controlled study. N Engl J Med 2015;372:1510-1518.

79. Sharquie KE, Helmi RM, Noiami AA, Al-Hayani RK, Kadhom MA. The therapeutic role of isotretinoin in the management of Behcet's disease: a single-blinded, controlled therapeutic study. J Drugs Dermatol 2013;12:e68-73.

80. Davatchi F, SadeghiAbdollahi B, Tehrani Banihashemi A, Shahram F, Nadji A, Shams H et al. Colchicine versus placebo in Behcet's disease: randomized, double-blind, controlled crossover trial. Mod Rheumatol 2009;19:542549.

81. Kilic H, Zeytin HE, Korkmaz C, Mat C, Gul A, Cosan F et al. Low-dose natural human interferon-alpha lozenges in the treatment of Behcet's syndrome. Rheumatology (Oxford) 2009;48:1388-1391.

82. Sun A, Wang YP, Chia JS, Liu BY, Chiang CP. Treatment with levamisole and colchicine can result in a significant reduction of IL-6, IL-8 or TNF-alpha level in patients with mucocutaneous type of Behcet's disease. J Oral Pathol Med 2009;38:401-405.

83. Ciancio G, Colina M, La Corte R, Lo Monaco A, De Leonardis F, Trotta F et al. Nicotine-patch therapy on mucocutaneous lesions of Behcet's disease: a case series. Rheumatology (Oxford) 2010;49:501-504.

84. Mumcu G, Inanc N, Ozdemir FT, Tulunay A, EksiogluDemiralp E, Ergun T et al. Effects of azithromycin on intracellular cytokine responses and mucocutaneous manifestations in Behcet's disease. Int J Dermatol 2013;52:1561-1566.

85. Tanida S, Inoue N, Kobayashi K, Naganuma M, Hirai F, Iizuka B et al. Adalimumab for the treatment of Japanese patients with intestinal Behcet's disease. Clin Gastroenterol Hepatol 2015;13:940-948 e943.

86. Nanke Y, Kamatani N, Okamoto T, Ogiuchi H, Kotake S. Irsogladine is effective for recurrent oral ulcers in patients with Behcet's disease : an open-label, single-centre study. Drugs R D 2008;9:455-459.

87. Melikoglu M, Fresko I, Mat C, Ozyazgan Y, Gogus F, Yurdakul S et al. Short-term trial of etanercept in Behcet's disease: a double blind, placebo controlled study. J Rheumatol 2005;32:98-105.

88. Kotter I, Vonthein R, Zierhut M, Eckstein AK, Ness T, Gunaydin I et al. Differential efficacy of human recombinant interferon-alpha2a on ocular and extraocular manifestations of Behcet disease: results of an open 4center trial. Semin Arthritis Rheum 2004;33:311-319.

89. Matsuda T, Ohno S, Hirohata S, Miyanaga Y, Ujihara H, Inaba $\mathrm{G}$ et al. Efficacy of rebamipide as adjunctive therapy in the treatment of recurrent oral aphthous ulcers in patients with Behcet's disease: a randomised, doubleblind, placebo-controlled study. Drugs R D 2003;4:19-28.

90. Alpsoy E, Durusoy C, Yilmaz E, Ozgurel Y, Ermis O, Yazar S et al. Interferon alfa-2a in the treatment of Behcet disease: a randomized placebo-controlled and doubleblind study. Arch Dermatol 2002;138:467-471.

91. Alpsoy E, Er H, Durusoy C, Yilmaz E. The use of sucralfate suspension in the treatment of oral and genital ulceration of Behcet disease: a randomized, placebocontrolled, double-blind study. Arch Dermatol 1999;135:529-532.

92. O'Duffy JD, Calamia K, Cohen S, Goronzy JJ, Herman $\mathrm{D}$, Jorizzo J et al. Interferon-alpha treatment of Behcet's disease. J Rheumatol 1998;25:1938-1944.

93. Hamuryudan V, Mat C, Saip S, Ozyazgan Y, Siva A, Yurdakul S et al. Thalidomide in the treatment of the mucocutaneous lesions of the Behcet syndrome. A 
randomized, double-blind, placebo-controlled trial. Ann Intern Med 1998;128:443-450.

94. Hamuryudan V, Yurdakul S, Serdaroglu S, Tuzun Y, Rosenkaimer F, Yazici H. Topical alpha interferon in the treatment of oral ulcers in Behcet's syndrome: a preliminary report. Clin Exp Rheumatol 1990;8:51-54.

95. Masuda K, Nakajima A, Urayama A, Nakae K, Kogure $\mathrm{M}$, Inaba G. Double-masked trial of cyclosporin versus colchicine and long-term open study of cyclosporin in Behcet's disease. Lancet 1989;1:1093-1096.

96. Davies UM, Palmer RG, Denman AM. Treatment with acyclovir does not affect orogenital ulcers in Behcet's syndrome: a randomized double-blind trial. $\mathrm{Br} \mathrm{J}$ Rheumatol 1988;27:300-302.

97. Sakpal TV. Sample size estimation in clinical trial. Perspect Clin Res 2010;1:67-69. 